\title{
Mast cell-derived tumour necrosis factor is essential for allergic airway disease
}

\author{
S. Reuter*, A. Heinz*, M. Sieren*, R. Wiewrodt*, E.W. Gelfand ${ }^{\#}$, M. Stassen ${ }^{\star}$, \\ R. Buhl* and C. Taube*,\#
}

ABSTRACT: Mast cells are thought to contribute to allergic airway disease. However, the role of mast cell-produced mediators, such as tumour necrosis factor (TNF), for the development of allergic airway disease is unclear.

In order to define the role of mast cells in acute allergic airway disease two strains of mast celldeficient mice (Kitw/Wv and Kitw-sh/W-sh) were studied.

Compared with their wild-type littermates, Kitw/Wv and Kitw-sh/W-sh mice developed significantly lower airway responsiveness to methacholine and less airway inflammation and goblet cell metaplasia, following sensitisation in the absence of adjuvant and airway challenge. Transfer of bone marrow-derived mast cells (BMMCs) from wild-type mice to Kitw-sh/W-sh mice reconstituted both airway responsiveness and inflammation to levels similar to those in sensitised and challenged wild-type mice. In contrast, sensitised Kitw-sh/W-sh mice reconstituted with BMMCs from TNF-deficient mice were still severely impaired in their ability to develop airway hyperresponsiveness, inflammation or goblet cell metaplasia following allergen challenge.

The present results demonstrate the significance of mast cells in the development of airway disease and highlight the importance of mast cell-derived tumour necrosis factor in these responses.

KEYWORDS: Asthma, immunology, mast cell, tumour necrosis factor

$\mathbf{A}$ sthma is a complex syndrome characterised by airway hyperresponsiveness (AHR), airway inflammation and airway obstruction [1]. An additional feature of allergic asthma is increased production of immunoglobulin (Ig)E in response to common environmental allergens, and a relationship between atopy and allergic asthma has been demonstrated in several studies [2, 3]. Many inflammatory cells, principally mast cells predominantly located at the mucosal interface between host and environment, have been implicated in the allergic airway response and are regarded as important effector cells in the allergic immune response. This is mainly due to the allergen-specific activation of these cells through the IgE-loaded high-affinity IgE receptor (FceRI) following contact with allergen. Indeed, increased numbers of mast cells have been found in human asthmatics in close proximity to airway smooth muscle suggesting a potential role for the development and maintenance of allergic airway disease [4].

Several studies in murine models [5-7] support potential roles for mast cells in allergic airway disease. Mast cells, following activation, are able to degranulate and produce a plethora of different mediators [8]. Some of those mediators have been implicated in the chemotaxis of T-cells that are important for the development of allergic airway disease [9-11]. One of the many proinflammatory cytokines is tumour necrosis factor (TNF), which can be pre-formed and stored in mast cells and released upon demand within minutes [12-14]. Interestingly, mast cell-derived TNF has been found to promote T-cell activation and proliferation $[15,16]$, as well as the migration of dendritic cells [17]. However, the role of mast cell-derived TNF for the development of allergic airway disease is not well described.

The aim of the present study was to investigate the role of mast cells and mast cell-produced TNF in the induction of allergic airway disease in a model of allergen sensitisation without adjuvant. It is shown herein that mast cell-deficient mice do not develop allergic airway disease following sensitisation in the absence of adjuvant and airway challenge. Additionally, the present authors demonstrate that TNF produced by mast
AFFILIATIONS

${ }^{*}$ III. Medical Clinic, Dept of

Pulmonary Medicine, and

"Institute for Immunology, University

of Mainz, Mainz, Germany.

"Division of Cell Biology, Dept of

Paediatrics, National Jewish Medical

and Research Center, Denver, CO,

USA.

CORRESPONDENCE

C. Taube

III. Medical Clinic

Dept of Pulmonary Medicine

Johannes Gutenberg University

Langenbeckstr. 1

55101 Mainz

Germany

Fax: 496131176668

E-mail: taube@3-med.klinik.uni-

mainz.de

Received:

May 152007

Accepted after revision:

December 122007

\section{SUPPORT STATEMENT}

The present study was funded by Deutsche Forschungsgemeinschaft (SFB 548, A11 to C. Taube, and A10 and STA984/1-1 to M. Stassen), NIH-grants HL-36577 and HL61005, and EPA grant R825702 (all to E.W. Gelfand and MAIFOR).

\section{STATEMENT OF INTEREST}

None declared. 
cells is essential for the development of AHR, airway inflammation and goblet cell metaplasia.

\section{METHODS \\ Mice}

$\mathrm{WB} / \mathrm{ReJ}-\mathrm{W} /+$ and $\mathrm{C} 57 \mathrm{Bl} / 6 \mathrm{~J}-\mathrm{W}_{\mathrm{v} /+}$ mice were obtained from Jackson Laboratory (Bar Harbor, ME, USA) and the mast celldeficient c-kit mutant F1-generation mice WBB6F1-KitW/W-v and the congenic WBB6F1-Kit+/+ were bred in the Zentrale Tierzuchtanstalt of the Johannes Gutenberg University Medical Center (Mainz, Germany). In addition, mast cell-deficient C57Bl/6-KitW-sh/W-sh mice and congenic C57Bl/6-Kit+/+ wildtype littermates were obtained by intercrossing C57Bl/6-KitWsh/+ mice kindly provided by M. Maurer (Charité, Berlin, Germany). C57Bl/6 mice deficient for TNF were obtained from K. Steinbrink (University of Mainz, Mainz, Germany). Mice were used at age 8-12 weeks. For reconstitution experiments mice were 14 weeks old at the time of sensitisation. Animal procedures were conducted in accordance with current institutional guidelines and performed according to the Helsinki convention for the use and care of animals.

\section{Experimental protocols}

Experimental groups consisted of three or four mice per group and each experiment was performed at least twice. Mice were sensitised by intraperitoneal (i.p.) injection of $100 \mu \mathrm{L}$ of $20 \mu \mathrm{g}$ ovalbumin (OVA; Sigma-Aldrich, St Louis, MO, USA) solution in phosphate buffered saline (PBS) on days 0 and 14. Mice were then challenged via the airways on days 28, 29 and 30, using nebulised OVA (1\% (weight/volume) in PBS) with an ultrasonic nebuliser (NE-U17; Omron, Hoofdorp, the Netherlands).

\section{Mast cell reconstitution}

In order to obtain bone marrow-derived mast cells (BMMCs), bone marrow from $\mathrm{C} 57 \mathrm{Bl} / 6$ mice was cultured for 4-5 weeks in Iscove's modified Dulbecco's medium (10\% (volume/ volume) foetal calf serum, $50 \mu \mathrm{M} \beta$-mercaptoethanol, $2 \mathrm{mM}$ glutamine, $100 \mu \mathrm{g} \cdot \mathrm{mL}^{-1}$ streptomycin, $100 \mathrm{U} \cdot \mathrm{mL}^{-1}$ penicillin, $20 \mathrm{U} \cdot \mathrm{mL}^{-1}$ m-interleukin-3 and $200 \mathrm{ng} \cdot \mathrm{mL}^{-1}$ kit-ligand) as described previously [18]. Nonadherent cells were transferred to fresh culture plates every $2-3$ days for a total of $\geqslant 21$ days in order to remove adherent macrophages and fibroblasts. After 4 weeks of culture, $>95 \%$ of nonadherent cells contained granules that stained positively with toluidine blue and $>95 \%$ expressed c-Kit on their surface as determined by fluorescenceactivated cell sorting analysis using anti-c-Kit m-antibody. In order to reconstitute the mast cell-deficient mice (6-weeks-old C57Bl/6-KitWsh/Wsh), 5x106 BMMCs were injected in the tail vein of each mouse. Sensitisation was started 8 weeks after the injection and airway challenges were performed at 12 weeks following BMMCs administration.

\section{Measurement of airway reactivity}

Measurements of airway resistance $(R \mathrm{~L})$ were performed on anaesthetised, intubated and mechanically ventilated (FlexiVent; Scireq, Montreal, QC, Canada) mice in response to increasing doses of inhaled methacholine (MCh; 6.25, 12.5, 25, 50 and $\left.100 \mathrm{mg} \cdot \mathrm{mL}^{-1}\right)$. Measurements of $R \mathrm{~L}$ were performed every $15 \mathrm{~s}$ following each nebulisation step until a plateau phase was reached.

\section{Bronchoalveolar lavage}

After assessment of airway function, lungs were lavaged via the tracheal tube with PBS $(1 \mathrm{~mL})$. Numbers of lavaged cells were counted using trypan blue dye exclusion. Differential cell counts were made from cytocentrifuged preparations fixed and stained with a Microscopy Hemacolor ${ }^{\circledR}-S e t$ (Merck, Darmstadt, Germany). Percentage and absolute numbers of each cell type were calculated. The numbers of CD3-, CD4- and CD8-positive cells was assessed by flow cytometry analysis using fluorescein isothiocyanate-conjugated monoclonal rat anti-mouse CD3 and phycoerythrin-conjugated rat anti-mouse CD4 or CD8 (all BD Bioscience Heidelberg, Germany). Absolute numbers of CD4-positive (CD3+/CD4+) and CD8positive (CD3+/CD8+) T-cells were calculated by multiplying the total cell count and the percentage of either CD3/CD4 or CD3/CD8 cells.

\section{Histology}

Lungs were fixed by inflation $(1 \mathrm{~mL})$ and immersion in $10 \%$ $(\mathrm{v} / \mathrm{v})$ formalin, and embedded in paraffin. Tissue sections were stained with haematoxylin and eosin (HE) and periodic acid-Schiff (PAS). In order to assess reconstitution efficiencies, sections were used for fluorescence staining of tissue specific for mast cells with Avidin-Alexa-488 (Molecular probes; Invitrogen, Karlsruhe, Germany) [19-21] or were stained with toluidine blue. Slides were examined in a blinded fashion with a microscope (BX40; Olympus, Hamburg, Germany). The number of mast cells and goblet cells were analysed respectively using Avidin-Alexa-488 and PAS-stained slides and imaging software (Analysis; Soft Imaging Systems, Stuttgart, Germany). For the assessment for mast cell numbers in each slide, mast cells were counted by a blinded investigator in five different fields and, in each field, the lung area was measured using an image analysis system. Numbers of mast cells are expressed as cells $\cdot \mathrm{cm}^{-2}[6,22]$ and numbers of goblet cells are expressed as cells $\cdot \mathrm{mm}^{-1}$ basement membrane (BM).

\section{Antigen-specific ELISA}

Serum was obtained $48 \mathrm{~h}$ following the last challenge. OVA specific IgG1 and IgG2b titres were determined using ELISA. Biotin-conjugated detection antibodies, streptavidin-horseradish peroxidase and substrat-reagent (BD-Pharmingen, Heidelberg, Germany), were used in concentrations recommended by the manufacturer. OVA-specific IgE was assessed using a method described by SPERGEL et al. [23]. Briefly, plates were coated with rat anti-mouse IgE (clone R35-72; BDPharmingen). Following administration of $3 \%(\mathrm{v} / \mathrm{v})$ bovine serum albumin-PBS for $2 \mathrm{~h}$, serial dilutions of sera were incubated overnight at $4{ }^{\circ} \mathrm{C}$. Then, biotin-labelled OVA was added for $2 \mathrm{~h}$ and absorption was read after addition of streptavidin-horseradish peroxidase and $o$-phenylenediamine. The antibody titre was defined as the reciprocal serum dilution yielding an optical density, measured at $450 \mathrm{~nm}$, of 0.2 after linear regression analysis.

\section{Statistical analysis}

ANOVA was used to determine the levels of difference between all groups. Comparisons for all pairs were performed by the Tukey-Kramer honest significant difference test. A pvalue $<0.05$ was considered to be significant. Values for all measurements are expressed as mean \pm SEM. 


\section{RESULTS}

Mast cells are not required for allergen-specific B-cell and $T$-cell responses

In order to assess the role of mast cells following sensitisation without adjuvant, two different strains of mast cell-deficient mice were sensitised with OVA and then challenged with inhaled OVA on three consecutive days. Following sensitisation and challenge, WBB6F1-KitW/Wv and C57Bl/6-KitW-sh/Wsh mice showed an increase in OVA-specific serum IgG1 and IgE titres, similarly to sensitised and challenged wild-type (WBB6F1-Kit+/+ and C57Bl/6-Kit+/+, respectively) mice (table 1). In addition, CD4+ T-cells derived from the spleens of sensitised and challenged mast cell-deficient and wild-type mice displayed a comparable response with respect to T-helper type 2 cytokine production after re-stimulation in vitro (see table in supplementary data).

\section{Mast cells are necessary for the development of allergic airway disease}

In order to investigate the role of mast cells in the development of AHR, lung function was assessed $48 \mathrm{~h}$ after the last allergen inhalation. Both strains of mast cell-deficient WBB6F1-KitW/Wv mice and C57Bl/6-KitW-sh/W-sh mice showed no increase in airway responsiveness compared with respective wild-type mice, which displayed increased airway responsiveness to $\mathrm{MCh}$ following sensitisation and challenge (fig. 1). As shown in figure 2a, wild-type mice developed an eosinophilia in the airways, whereas in mast cell-deficient mice only few eosinophils appeared in the bronchoalveolar lavage (BAL) fluid. Additionally, numbers of CD4+ and CD8+ T-cells in BAL fluid were significantly lower in sensitised and challenged C57Bl/6-KitW-sh/W-sh mice compared with wild-type mice (fig. 2b). A reduction in tissue inflammation was also evident in HE-stained sections of lung tissue derived from mast celldeficient mice compared with their congenic littermates after sensitisation and challenge (fig. 3a, d, g and j). Using PAS staining (fig. 3b, c, e, f, h, i, k and l), significantly reduced numbers $(p<0.01)$ of goblet cells in airway epithelia of sensitised and challenged $\mathrm{C} 57 \mathrm{Bl} / 6-\mathrm{KitW}$-sh/W-sh mice were seen $\left(27 \pm 8\right.$ versus $93 \pm 8$ PAS-positive cells $\cdot \mathrm{mm}^{-1} \mathrm{BM}$ in C57Bl/ 6 -KitW-sh/W-sh and wild-type mice, respectively; $\mathrm{p}<0.01$, $\mathrm{n}=12$ ). Using the same model, decreased airway inflammation, failure to develop AHR and reduced numbers of goblet cells were also confirmed using WBB6F1-KitW/Wv animals, a different mouse strain that is also devoid of mast cells (data not shown).

Mast cell-derived TNF is pivotal for the development of AHR

Previous studies have shown that mast cell function can be restored in mast cell-deficient mice by transfer of BMMCs [5, 6]. Taking advantage of this technique, the role of mast cellderived TNF was examined in the present model of acute allergic airway disease. To this end, BMMCs were obtained from either $\mathrm{C} 57 \mathrm{Bl} / 6-\mathrm{TNF}+/+$ or $\mathrm{C} 57 \mathrm{Bl} / 6-\mathrm{TNF}-/$ - donors. Following cross-linking of FceRI in vitro, no differences in degranulation and production of cytokines (IL-4, -6 and -13) were found between the TNF-deficient mast cells and wildtype mast cells except for the production of TNF, which was absent in the BMMCs from C57Bl/6-TNF-/- donors (data not shown).

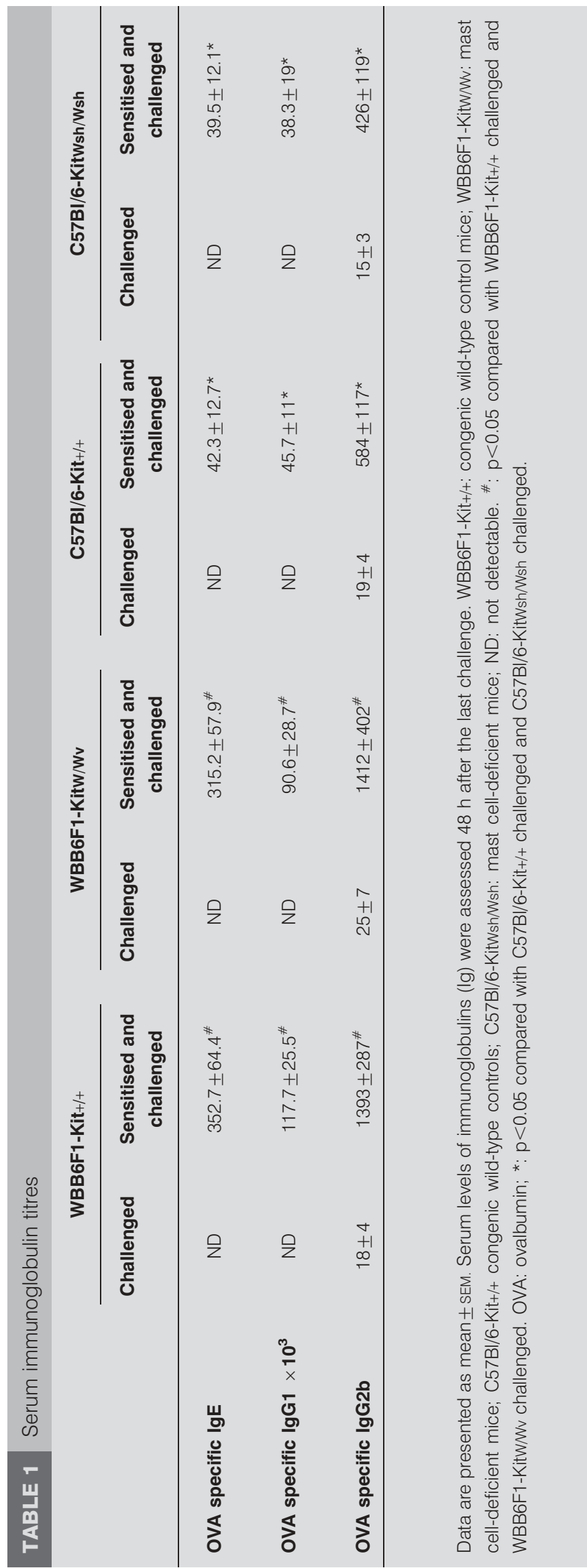



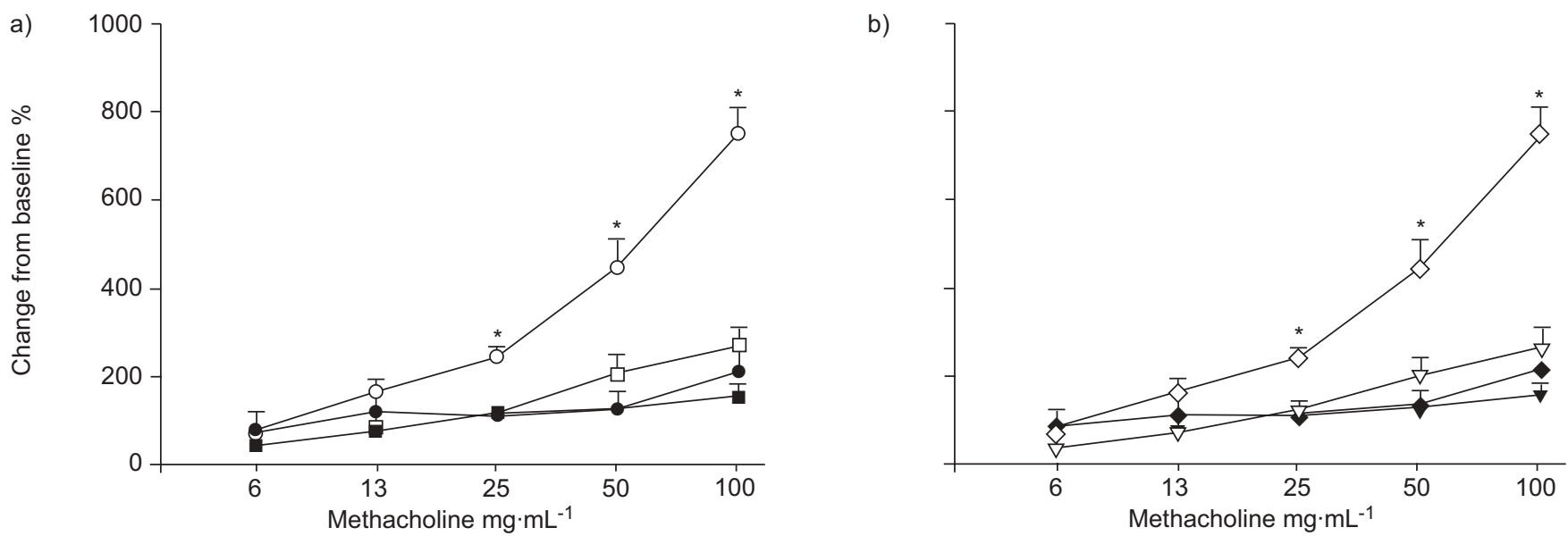

FIGURE 1. Airway responsiveness in mast cell-deficient mice. a) Airway responsiveness (resistance) in challenged only $(\mathbf{\square} ; n=10)$ and sensitised and challenged ( $\square$; $\mathrm{n}=10)$ WBB6F1-Kitw/W-v mice, and in challenged only $(\bullet ; n=10)$ and sensitised and challenged $(O ; n=10)$ wild-type (WBB6F1-Kit+/+) mice. b) Airway responsiveness in challenged only $(\mathbf{\nabla} ; \mathrm{n}=12)$ and sensitised and challenged $(\nabla ; \mathrm{n}=12)$ C57B//6-KitW-sh $/$-sh mice, and in challenged only $(\bullet ; \mathrm{n}=12)$ and sensitised and challenged $(\diamond ; \mathrm{n}=12)$ wild-type (C57BI/6-Kit+/+) mice. Data are shown as mean \pm SEM. *: $p<0.05$ compared with all other groups.
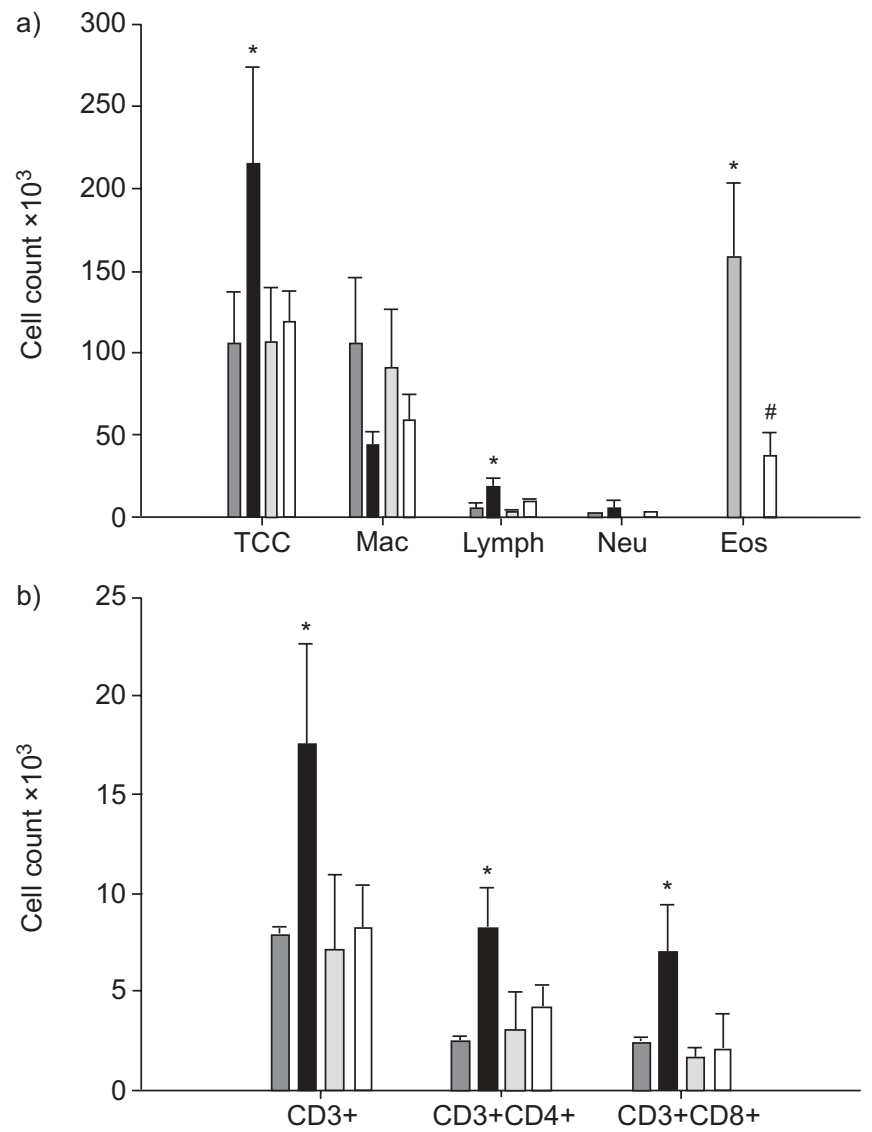

FIGURE 2. Airway inflammation in bronchoalveolar lavage (BAL) fluid. a) Differential cell count and b) number of CD4+ and CD8+ T-cells were assessed in BAL fluid of challenged only $(\square ; n=12)$ and sensitised and challenged C57BI/6Kit+/+ $(\mathbb{\square} ; n=12)$ mice, and challenged only $(\square ; n=12)$ and sensitised and challenged C57BI/6-Kitw-sh/W-sh ( $\square$; $\mathrm{n}=12)$ mice. Data are shown as mean \pm SEM. TCC: total cell count; Mac: macrophages; Lymph: lymphocytes; Neu: neutrophils; Eos: eosinophils. *: $p<0.05$ compared with all other groups; ${ }^{*}: p<0.05$ compared with C57BI/6-Kit+/+ challenged only and C57BI/6-KitW-sh/W-sh challenged-only mice.
BMMCs derived from $\mathrm{C} 57 \mathrm{Bl} / 6-\mathrm{TNF}+/+$ or $\mathrm{C} 57 \mathrm{Bl} / 6-\mathrm{TNF}-/-$ donors were transferred to $\mathrm{C} 57 \mathrm{Bl} / 6-\mathrm{KitW}$-sh/W-sh recipient mice. Recipient mice were sensitised and challenged 8 weeks after reconstitution. In mice reconstituted with mast cells from $\mathrm{C} 57 \mathrm{Bl} / 6-\mathrm{TNF}+/+$ animals $(\mathrm{n}=9), 35 \pm 12$ mast cells $\cdot \mathrm{cm}^{-2}$ were detected compared with $20 \pm 5$ cells $\cdot \mathrm{cm}^{-2}$ following reconstitution with mast cells from C57Bl/6-TNF-/- donors ( $n=9 ; \mathrm{p}>0.05$ compared to all other groups) and $30 \pm 12$ cells $\cdot \mathrm{cm}^{-2}$ in sensitised and challenged wild-type mice $(n=9$; fig. 4 and figure in supplementary data).

C57Bl/6-KitW-sh/W-sh mice reconstituted with wild-type BMMCs showed airway responsiveness similar to sensitised and challenged wild-type mice (fig. 5). In contrast, reconstitution of mast cell-deficient mice with BMMCs derived from C57Bl/6-TNF-/- donors did not restore AHR (fig. 5). This clearly indicates an important role of mast cell-derived TNF for the development of AHR.

\section{Airway inflammation and goblet cell metaplasia in mast cell- deficient mice cannot be restored upon transfer of TNF- deficient mast cells}

Using reconstitution experiments, the influence of mast cells and mast cell-derived TNF on airway inflammation and goblet cell hyperplasia was analysed. As summarised in figures 4 and 6, numbers of eosinophils and T-cells in BAL (fig. 6), as well as cellular infiltration in the lungs (figs $4 a-e$ ) and number of goblet cells (figs $4 \mathrm{f}-\mathrm{j}$ and table 2 ), were restored to wild-type levels upon transfer of wild-type BMMCs into mast celldeficient mice. However, reconstitution of mast cell-deficient mice with BMMCs derived from C57Bl/6-TNF-/- donors did not restore airway inflammation (figs 4 and 6) and goblet cell metaplasia (fig. 4 and table 2).

\section{DISCUSSION}

Several lines of evidence support a pivotal role of mast cells for the development of allergic asthma, but currently very little is known about the underlying mechanisms and mediators involved in these mast cell-dependent responses. In the 

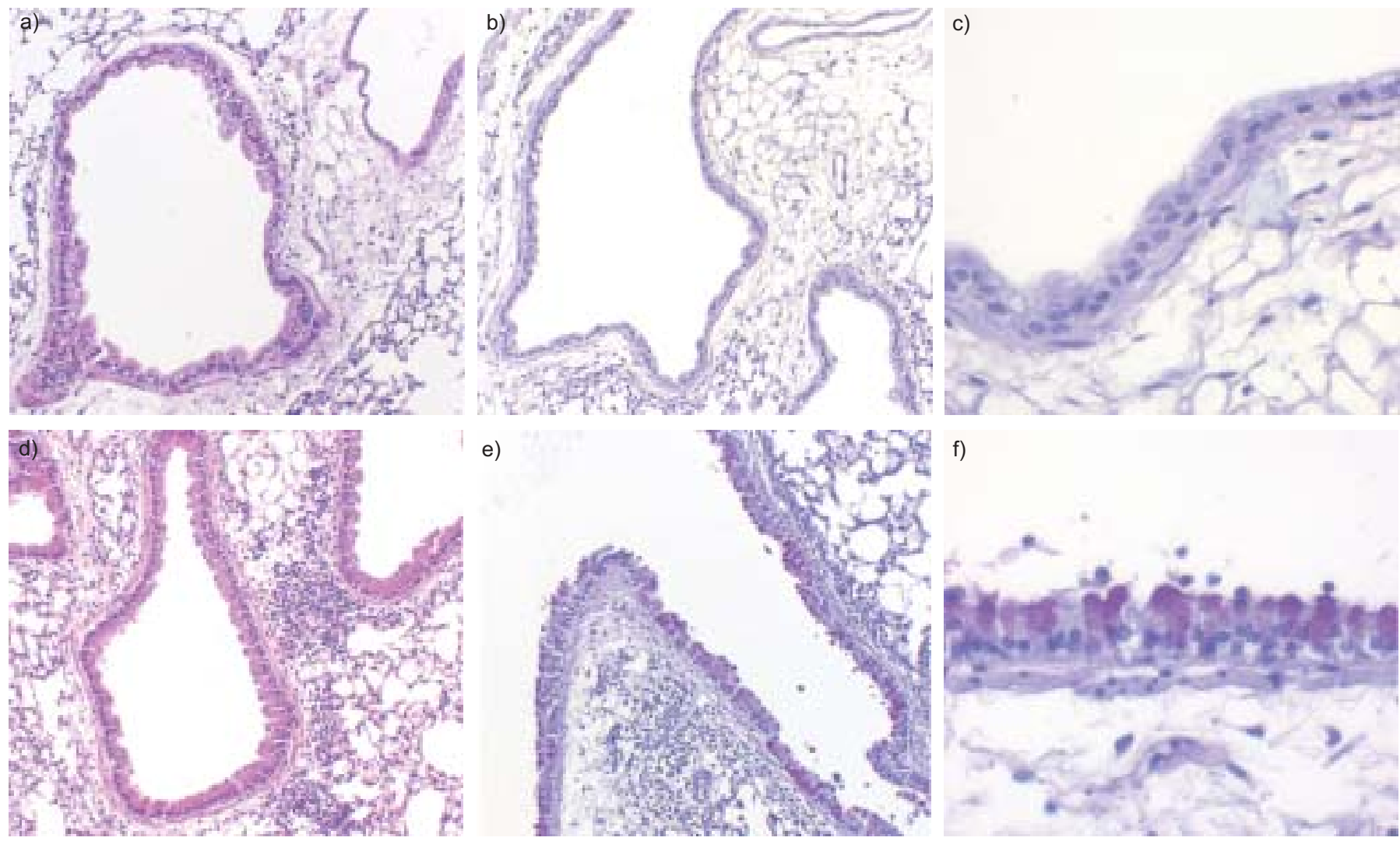

e)
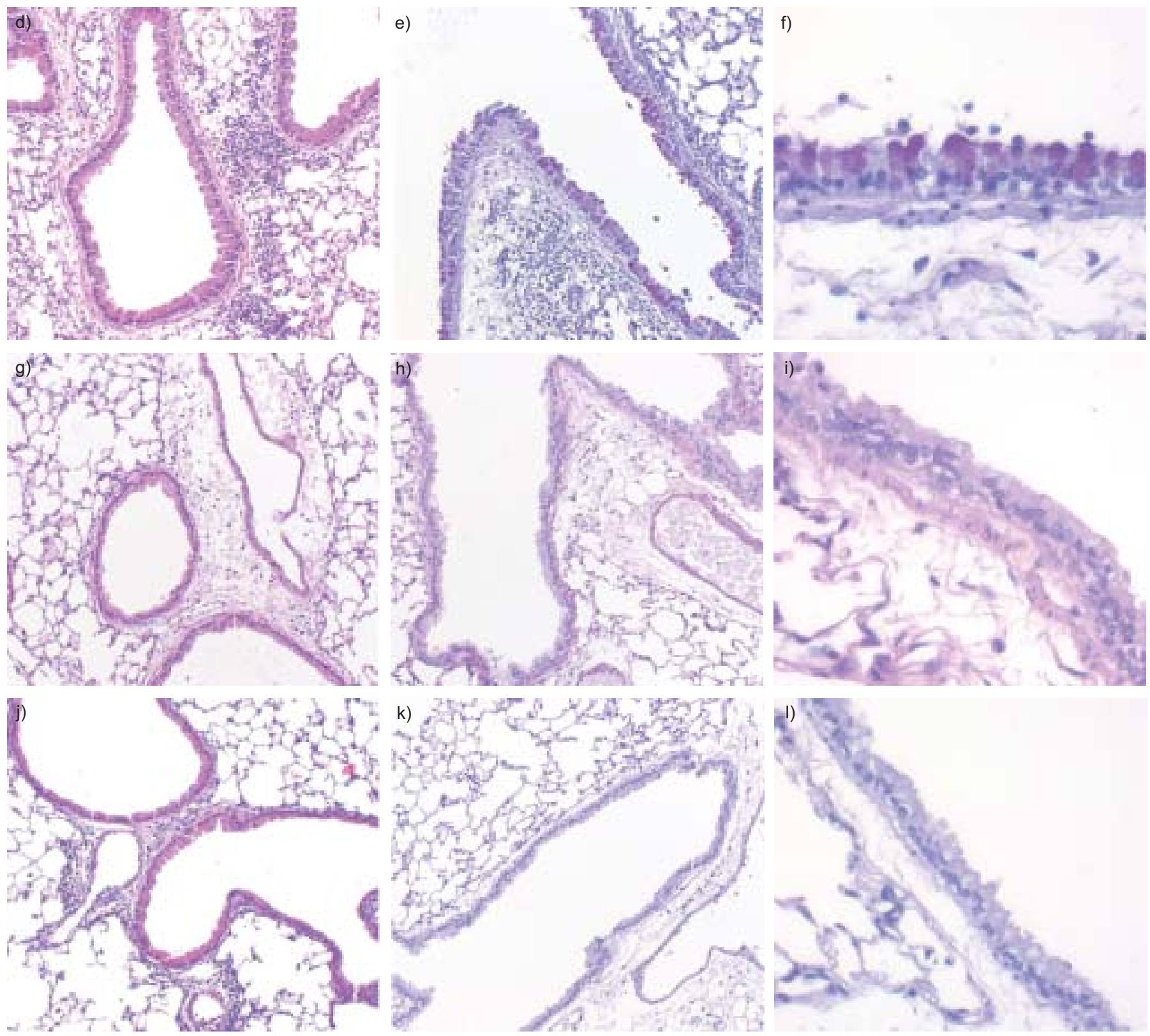

FIGURE 3. Tissue inflammation and goblet cell metaplasia in mast cell-deficient mice. Tissue inflammation was evaluated $48 \mathrm{~h}$ after the last challenge using haematoxylin and eosin staining ( $\mathrm{a}, \mathrm{d}, \mathrm{g}$ and $\mathrm{j})$ and periodic acid-Schiff staining (b, c, e, f, h, i, k and l) for goblet cells in challenged-only C57B//6-Kit+/+ (a-c), sensitised and challenged C57BI/6-Kit+/+ (d-f), challenged-only C57BI/6-KitW-sh/W-sh (g-i) and sensitised and challenged C57BI/6-KitW-sh/W-sh (j-I) mice. 

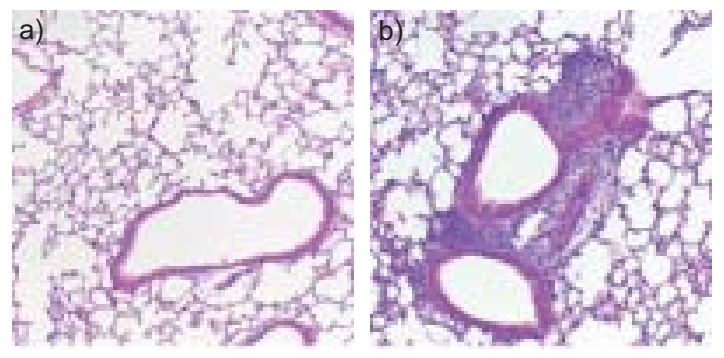

f)

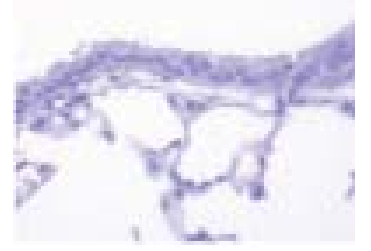

g)
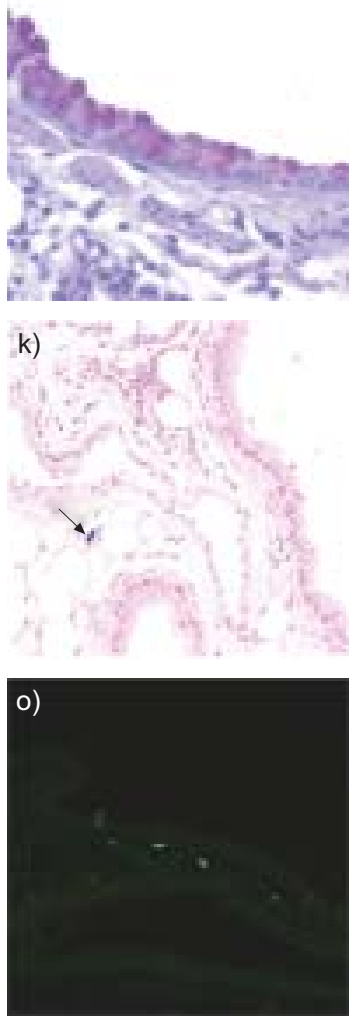
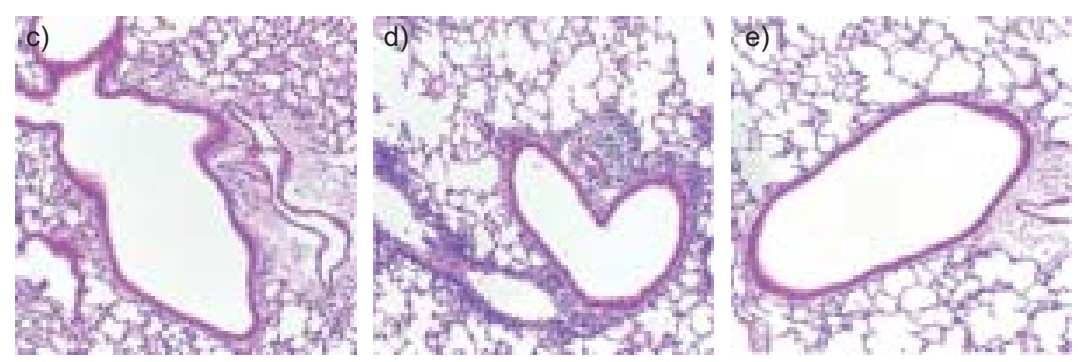

h)

i)
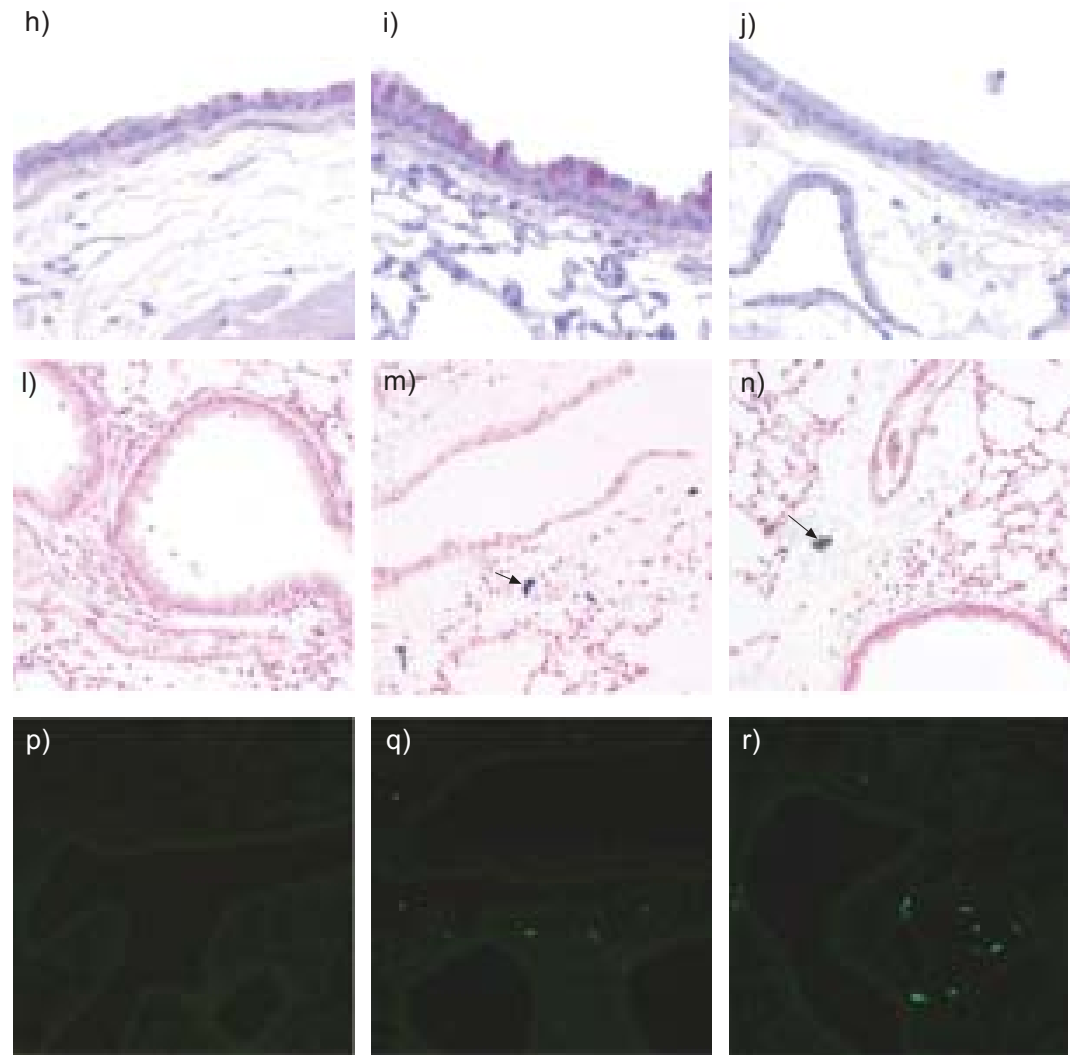

FIGURE 4. Tissue inflammation and goblet cell metaplasia in mast cell-deficient mice. Tissue inflammation was evaluated $48 \mathrm{~h}$ after the last challenge using haematoxylin and eosin staining (a-e), periodic acid-Schiff staining for goblet cells $(\mathrm{f}-\mathrm{j})$ and toluidine blue $(\mathrm{k}-\mathrm{n})$ and Avidin-Alexa-488 (o-r) staining for mast cells in challenged-only C57BI/6-Kit+/+ mice (a and f), sensitised and challenge C57BI/6-Kit+/+ mice (b, g, k and o), sensitised and challenge C57BI/6-KitW-sh/N-sh mice (c, h, I and p), sensitised and challenge C57B//6-Kitw-sh/W-sh mice reconstituted with bone marrow-derived mast cells (BMMCs) from wild-type mice (d, i, $m$ and q) and sensitised and challenged C57BI/6-KitW-sh/W-sh mice reconstituted with BMMCs from tumour necrosis factor-deficient mice (e, j, $\mathrm{n}$ and r). Arrows mark toluidine blue-stained cells.

present study, an acute model of allergic airway disease shows that, following sensitisation without adjuvant and challenge of the mice, mast cells are necessary for the development of AHR and airway inflammation. Furthermore, mast cell-derived TNF is shown to be an essential mediator for the development of these responses in the present model.

Mast cells have been postulated as important effector cells in allergic airway disease for a long time. However, the role and contribution of mast cells to the development of allergic airway disease appears to be highly dependent on the sensitisation and allergen exposure protocol in murine models. Studies using models of systemic sensitisation with adjuvant have repeatedly shown a similar degree of AHR and airway inflammation in mast cell- or IgE-deficient mice compared with respective wild-type mice [24-26]. In several different models with less potent sensitisation protocols, mast cells have been implicated to be necessary for the induction of nonallergic [27] but also allergen-induced airway disease [5-7, 28, 29]. In the present study, the authors show that following systemic allergen sensitisation without adjuvant and airway challenge, levels of allergen-specific IgE and IgG1 and allergen-induced proliferation of $\mathrm{T}$-cells remained intact in both mast celldeficient mouse strains. Also increased levels of OVA-specific $\operatorname{IgG} 2 b$ were detected. However, these were much lower compared with OVA-specific IgG1 levels, suggesting a predominant Th2 response in these animals. These findings and previous studies [6] suggest that, after systemic introduction of the allergen, sensitisation is not impaired in mast celldeficient mice. In contrast, development of key features of allergic airway disease, including AHR, airway inflammation, migration of T-cells into the lung and goblet cell metaplasia, 


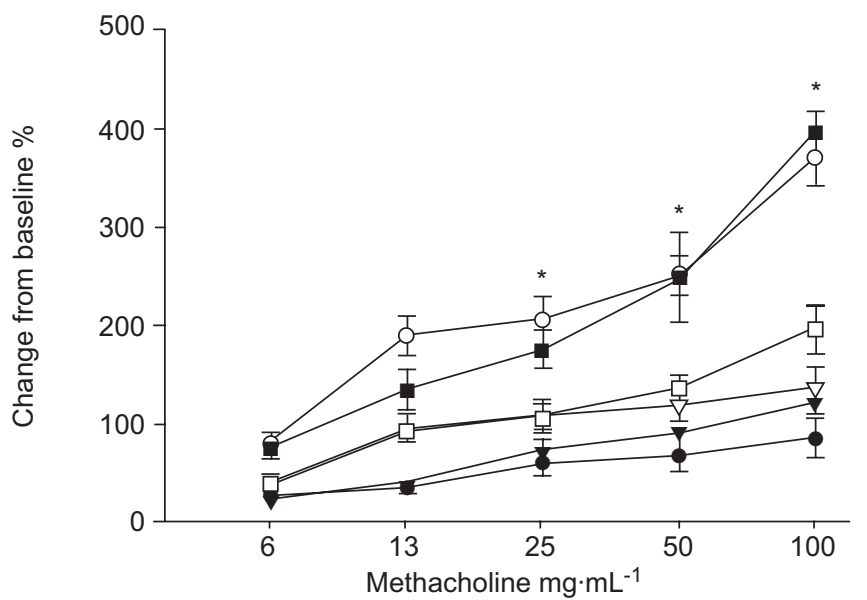

FIGURE 5. Airway responsiveness in mast cell-deficient mice following reconstitution with wild-type and tumour necrosis factor (TNF)- $\alpha$ deficient bone marrow-derived mast cells (BMMCs). Airway reactivity was assessed following sensitisation and challenge in C57BI/6-KitW-sh/W-sh reconstituted with either BMMCs derived from wild-type mice $(\mathbf{\square} ; n=9)$ or TNF-deficient mice $(\square ; n=9)$ and compared with challenged wild-type mice $(\bullet ; n=9)$, sensitised and challenged wild-type mice $(O ; n=9)$, challenged C57BI/6-Kitw-sh/W-sh mice $(\mathbf{\nabla} ; n=9)$ and sensitised and challenged C57BI/6-Kitw-sh/W-sh mice that were not reconstituted with mast cells $(\nabla ; n=9)$. Data are presented as mean \pm SEM. *: $p<0.05$ compared with C57B//6-KitW-sh/W-sh reconstituted with BMMCs derived from TNF-deficient, challenged-only C57B//6-Kit+/+, challenged-only C57BI/6-Kitw-sh/W-sh, and sensitised and challenged C57BI/6-Kitw-sh/W-sh mice.

are decreased in both mast cell-deficient mouse strains, suggesting an important role for mast cells in mediating allergen-induced responses.

Transfer of BMMCs to mast cell-deficient mice has been shown to reconstitute mast cells in many organs but also the lungs of the recipient mice $[22,30]$. Previous studies by WILLIAMS and GALLI [5] and Yu et al. [6] in a more chronic model of allergic airway disease have also demonstrated that BMMC administration to mast cell-deficient mice reconstituted the features of allergic airway disease. Similarly, in the present study using a more acute model, transfer of BMMCs derived from $\mathrm{C} 57 \mathrm{Bl} / 6$ $\mathrm{Kit}+/+$ mice to $\mathrm{C} 57 \mathrm{Bl} / 6-\mathrm{KitW}$-sh/W-sh recipients resulted in detectable mast cells in lung tissue accompanied by AHR, increased airway inflammation and goblet cell metaplasia in sensitised and challenged recipients to levels seen in sensitised and challenged wild-type mice.

Mast cells can be activated through different stimuli [31] primarily through IgE/allergen-mediated crosslinking of FceRI in the context of allergic airway disease [32, 33]. YU et al. [6] showed that the expression of the Fc receptor for IgG (FCR $\gamma$ chain) in mast cells, which is necessary for the surface expression of the FCR $\gamma$-chains I and III and FccRI receptor, is critical for the induction of most features of allergen induced lung pathology. Studies in a model of allergen inhalation have suggested that activation through FceRI, which in mice is only displayed on mast cells and basophils [32], contributed to increased airway reactivity [7]. Despite several studies demonstrating a contribution of mast cells in the development of acute and chronic allergic airway disease, little is known about
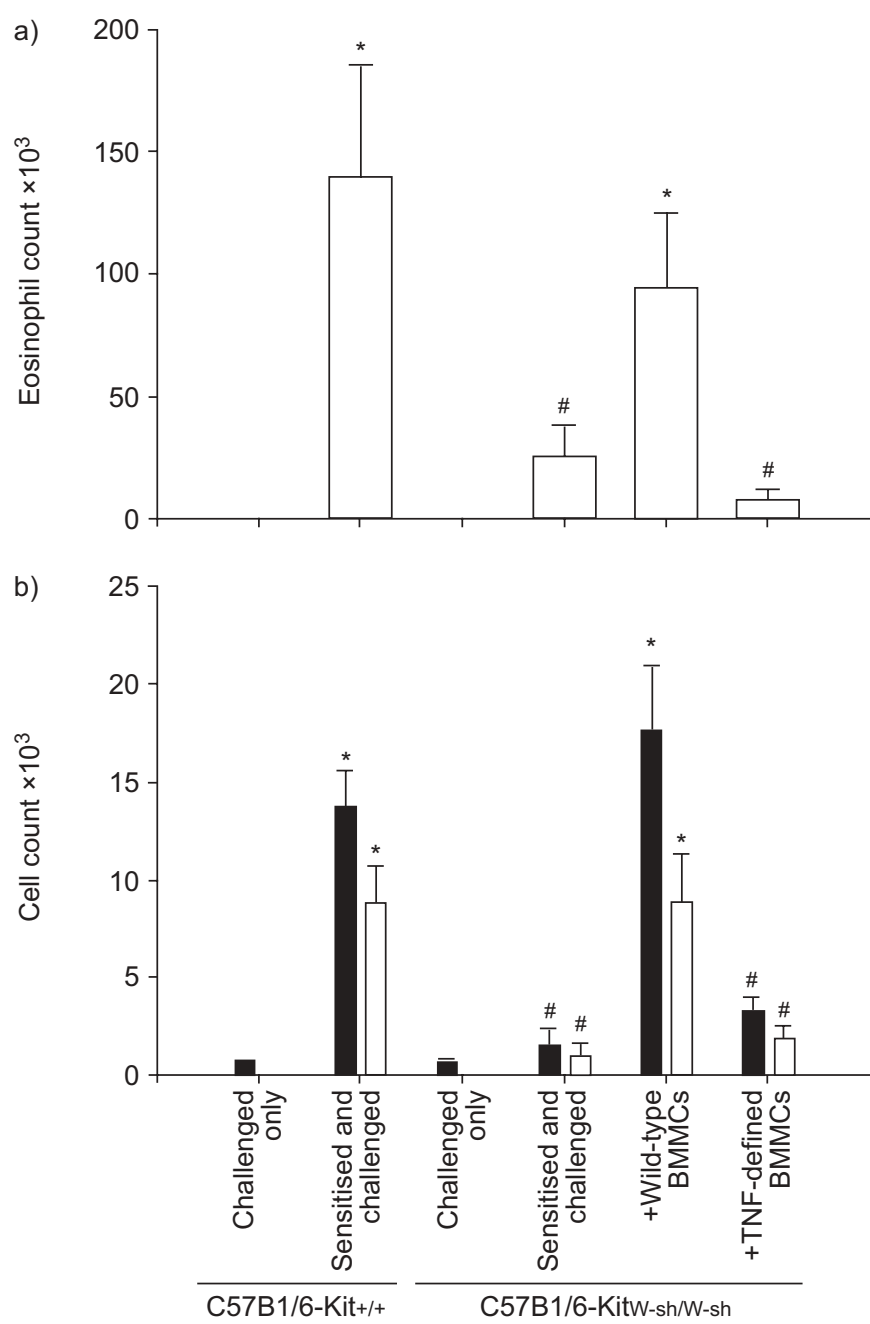

FIGURE 6. Eosinophil, CD4+ and CD8+ T-cell numbers in bronchoalveolar lavage (BAL) fluid. a) Number of eosinophils and b) number of CD4+ ( $\mathbf{\square}$ ) and CD8+ ( $\square$ ) T-cells were assessed in the BAL of wild-type mice (C57BI/6-Kit+/+) which were challenged only or sensitised and challenged, and in C57BI/6-Kitw-sh/W-sh mice which were challenged only, sensitised and challenged and sensitised or challenged following reconstitution with bone marrow-derived mast cells (BMMCs) from wild-type (+wild-type BMMCs) or tumour necrosis factor (TNF)deficient (TNF-deficient BMMCs) mice. Data are shown as mean \pm SEM from three independent experiments and $\mathrm{n}=9$ for all conditions. ${ }^{*}: \mathrm{p}<0.05$ compared with al other groups; ${ }^{*}$ : $p<0.05$ compared with C57B//6-Kit+/+ challenged-only and C57BI/ 6 -Kitw-sh/W-sh challenged-only mice.

which mast cell-derived mediator(s) may be necessary for these responses. Following activation, mast cells are capable of producing a wide variety of mediators, including histamine, lipid mediators, chemokines and cytokines. Some of these mediators have been linked to the development of allergic airway disease, but it remains unclear whether mast cells are an essential source for them, as other cells types might also contribute to their production. Indeed, IL-13 has been repeatedly shown to be a central effector cytokine in allergic airway disease [34-36]. However, the production of IL-13 by mast cells does not seem to be necessary for the induction of increased airway reactivity following inhaled allergen challenge [7]. 


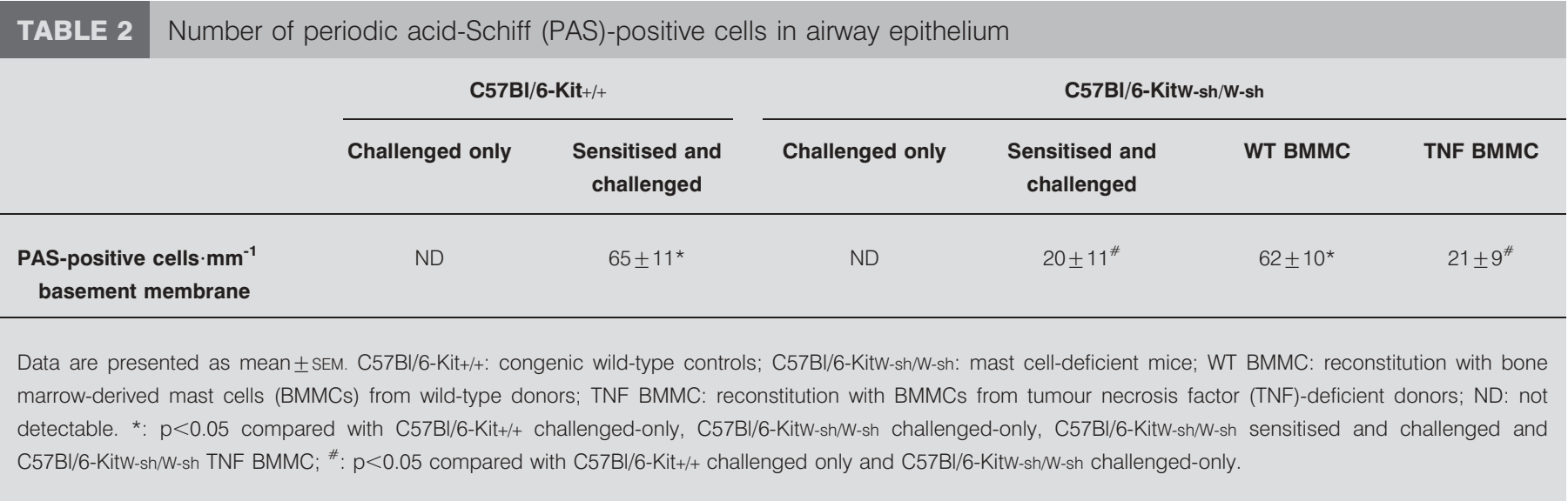

Conversely, specialised adoptive transfer models have suggested a role of mast cell-produced lipid mediators for recruitment of allergen-specific CD8+ T-effector cells into the lung [11], which are necessary for the development of allergen specific lung pathology [10]. In the present study, a decrease in CD4+ as well as CD8+ T-cells was detected in BAL fluid of the sensitised and challenged mast cell-deficient mice, suggesting impaired T-cell migration or local expansion in the lung consequent to the missing mast cell stimuli.

A mediator which has been implicated in many mast celldependent inflammatory responses is TNF. In agreement with the aforementioned reports, mast cell-deficient mice reconstituted with BMMCs from TNF-deficient donors in the present study failed to develop significant AHR following sensitisation and challenge. In addition, other features of allergic airway disease, such as airway inflammation and goblet cell metaplasia, were not reconstituted in mice engrafted with TNFdeficient mast cells, implicating a critical role of mast cellderived TNF for the development of allergic airway disease. Mast cells have the capability to store and rapidly release TNF following activation $[37,38]$. In other disease models, mast cellderived TNF has been identified as being important for the induction and promotion of initial inflammatory events, e.g. in models of immune complex-induced inflammation [39], acute septic peritonitis [40], cutaneous inflammation [41], colitis [42], delayed-type hypersensitivity reactions [43] and pulmonary hypersensitivity reactions [44]. Several studies have also suggested a contribution of TNF during the induction of allergic airway disease. Following IgE-dependent stimulation of human lung tissue, TNF is produced in amounts sufficient to induce biological effects [45]. Additionally, administration of TNF into the lungs of mice induces increased airway mucus gene expression [46] and late airway response [47]. Recently, in TNF-deficient mice, a reduction in AHR and airway inflammation following a protocol of systemic sensitisation without an additional adjuvant and airway challenge was demonstrated [48]. Following allergen challenge, WBB6F1-KitW/Wv mice expressed lower levels of TNF in BAL fluid and reconstitution with wild-type BMMCs restored BAL fluid levels of TNF and AHR [49]. Independently confirming the present results, NAKAE et al. [50] reported that mast celldeficient mice reconstituted with BMMCs deficient in TNF failed to reconstitute the development of AHR. In a model of allergic airway disease different from the one used in the present experiments, it was shown that development of airway inflammation and goblet cell hyperplasia was impaired following reconstitution of $\mathrm{C} 57 \mathrm{Bl} / 6-\mathrm{KitW}$-sh/W-sh mice with TNF-deficient BMMCs but not with wild-type BMMCs. The findings of the present study are in agreement with those results and extend them to a different model of allergic airway disease. The comparable results in two independent studies underscore the importance of mast cell-produced TNF. The clinical relevance of these latter findings was strengthened by recent studies in patients with moderate [51] and more severe asthma $[52,53]$, where the beneficial effects of treatment with TNF-neutralising antibodies were described. The fact that treatment with TNF-neutralising antibodies has shown promising first results in humans further supports the view that TNF is a potent therapeutic target for patients with allergic asthma.

The underlying mechanisms by which mast cell-derived TNF affects the different features of allergic airway disease remain to be elucidated. Based on current knowledge, it is conceivable that migration of dendritic cells from the lung to the regional lymph nodes is impaired in the presence of TNF-deficient mast cells [54]. This assumption is substantiated by reports showing that IgE-dependent mast cell activation induces Langerhans cell migration [55] and that mast cell-derived TNF directly influences dendritic cell migration from the lung [17]. However, a direct effect on T-cells, which are thought to orchestrate the allergic response [1], is just as conceivable, as TNF from mast cells can directly influence T-cell activation and proliferation [15, 16]. Indeed, NAKAE et al. [50] suggest an increase in T-cell activation triggered by mast cell-produced TNF as the main modulator for the development of AHR and airway inflammation.

In summary, the present study demonstrates a critical role of mast cells for the development of acute allergic airway disease following sensitisation without an adjuvant. This finding is in agreement with models of more chronic protocols [5, 6]. Based on the reconstitution experiments with tumour necrosis factordeficient mast cells the pivotal role for mast cell-derived tumour necrosis factor in the allergen-induced development of 
airway hyperresponsiveness, airway inflammation and goblet cell metaplasia after allergen exposure of the sensitised host was identified.

\section{ACKNOWLEDGEMENTS}

The authors would like to thank K. Steinbrink (Dept of Dermatology, University of Mainz, Mainz, Germany) for generously providing C57Bl/6-TNF-/- bone marrow, and Marcus Maurer (Dept of Dermatology, Charité, Berlin, Germany) for providing the C57Bl/6-KitW-sh/+ mouse strain.

\section{REFERENCES}

1 Busse WW, Lemanske RF Jr. Asthma. N Engl J Med 2001; 344: 350-362.

2 Burrows B, Martinez FD, Halonen M, Barbee RA, Cline MG. Association of asthma with serum IgE levels and skin-test reactivity to allergens. N Engl J Med 1989; 320: 271-277.

3 Peat JK, Tovey E, Toelle BG, et al. House dust mite allergens. A major risk factor for childhood asthma in Australia. Am J Respir Crit Care Med 1996; 153: 141-146.

4 Brightling CE, Bradding P, Symon FA, Holgate ST, Wardlaw AJ, Pavord ID. Mast-cell infiltration of airway smooth muscle in asthma. N Engl J Med 2002; 346: 1699-1705.

5 Williams CM, Galli SJ. Mast cells can amplify airway reactivity and features of chronic inflammation in an asthma model in mice. J Exp Med 2000; 192: 455-462.

6 Yu M, Tsai M, Tam SY, Jones C, Zehnder J, Galli SJ. Mast cells can promote the development of multiple features of chronic asthma in mice. J Clin Invest 2006; 116: 1633-1641.

7 Taube C, Wei X, Swasey CH, et al. Mast cells, FceRI, and IL13 are required for development of airway hyperresponsiveness after aerosolized allergen exposure in the absence of adjuvant. J Immunol 2004; 172: 6398-6406.

8 Galli SJ, Nakae S, Tsai M. Mast cells in the development of adaptive immune responses. Nat Immunol 2005; 6: 135-142.

9 Ott VL, Cambier JC, Kappler J, Marrack P, Swanson BJ. Mast cell-dependent migration of effector CD8+ T cells through production of leukotriene B4. Nat Immunol 2003; 4: 974-981.

10 Miyahara N, Swanson BJ, Takeda K, et al. Effector CD8+ T cells mediate inflammation and airway hyper-responsiveness. Nat Med 2004; 10: 865-869.

11 Taube C, Miyahara N, Ott V, et al. The leukotriene B4 receptor (BLT1) is required for effector CD8+ T cellmediated, mast cell-dependent airway hyperresponsiveness. J Immunol 2006; 176: 3157-3164.

12 Gordon JR, Galli SJ. Mast cells as a source of both preformed and immunologically inducible TNF- $\alpha$ /cachectin. Nature 1990; 346: 274-276.

13 Echtenacher B, Männel DN, Hültner L. Critical protective role of mast cells in a model of acute septic peritonitis. Nature 1996; 381: 75-77.

14 Malaviya R, Ikeda T, Ross E, Abraham SN. Mast cell modulation of neutrophil influx and bacterial clearance at sites of infection through TNF- $\alpha$. Nature 1996; 381: 77-80.

15 Nakae S, Suto H, Kakurai M, Sedgwick JD, Tsai M, Galli SJ. Mast cells enhance T cell activation: Importance of mast cellderived TNF. Proc Natl Acad Sci USA 2005; 102: 6467-6472.
16 Nakae S, Suto H, Iikura M, et al. Mast cells enhance T cell activation: importance of mast cell costimulatory molecules and secreted TNF. J Immunol 2006; 176: 2238-2248.

17 Suto H, Nakae S, Kakurai M, Sedgwick JD, Tsai M, Galli SJ. Mast cell-associated TNF promotes dendritic cell migration. J Immunol 2006; 176: 4102-4112.

18 Klein M, Klein-Hessling S, Palmetshofer A, et al. Specific and redundant roles for NFAT transcription factors in the expression of mast cell-derived cytokines. J Immunol 2006; 177: 6667-6674.

19 Bergstresser PR, Tigelaar RE, Tharp MD. Conjugated avidin identifies cutaneous rodent and human mast cells. J Invest Dermatol 1984; 83: 214-218.

20 Bussolati G, Gugliotta P. Nonspecific staining of mast cells by avidin-biotin-peroxidase complexes (ABC). J Histochem Cytochem 1983; 31: 1419-1421.

21 Heib V, Becker M, Warger T, et al., Mast cells are crucial for early inflammation, migration of Langerhans cells and CTL responses following topical application of TLR7 ligand in mice. Blood 2007; 110: 946-953.

22 Wolters PJ, Mallen-St Clair J, Lewis CC, et al. Tissueselective mast cell reconstitution and differential lung gene expression in mast cell-deficient $\mathrm{Kit}(\mathrm{W}$-sh $) / \mathrm{Kit}(\mathrm{W}$-sh) sash mice. Clin Exp Allergy 2005; 35: 82-88.

23 Spergel JM, Mizoguchi E, Brewer JP, Martin TR, Bhan AK, Geha RS. Epicutaneous sensitization with protein antigen induces localized allergic dermatitis and hyperresponsiveness to methacholine after single exposure to aerosolized antigen in mice. J Clin Invest 1998; 101: 1614-1622.

24 Mehlhop PD, van de Rijn M, Goldberg AB, et al. Allergen-induced bronchial hyperreactivity and eosinophilic inflammation occur in the absence of $\operatorname{IgE}$ in a mouse model of asthma. Proc Natl Acad Sci U S A 1997; 94: 1344-1349.

25 Nogami M, Suko M, Okudaira H, et al. Experimental pulmonary eosinophilia in mice by Ascaris suum extract. Am Rev Respir Dis 1990; 141: 1289-1295.

26 Takeda K, Hamelmann E, Joetham A, et al. Development of eosinophilic airway inflammation and airway hyperresponsiveness in mast cell-deficient mice. J Exp Med 1997; 186: 449-454.

27 Kraneveld AD, van der Kleij HP, Kool M, et al. Key role for mast cells in nonatopic asthma. J Immunol 2002; 169: 2044-2053.

28 Kung TT, Stelts D, Zurcher JA, et al. Mast cells modulate allergic pulmonary eosinophilia in mice. Am J Respir Cell Mol Biol 1995; 12: 404-409.

29 Ogawa K, Kaminuma O, Kikkawa H, et al. Primary role of CD4+ T cells and supplemental role of mast cells in allergic pulmonary eosinophilia. Int Arch Allergy Immunol 1999; 120: Suppl. 1, 15-18.

30 Grimbaldeston MA, Chen CC, Piliponsky AM, Tsai M, Tam SY, Galli SJ. Mast cell-deficient W-sash c-kit mutant Kit W-sh/W-sh mice as a model for investigating mast cell biology in vivo. Am J Pathol 2005; 167: 835-848.

31 Stassen M, Hültner L, Schmitt E. Classical and alternative pathways of mast cell activation. Crit Rev Immunol 2002; 22 115-140.

32 Kinet JP. The high-affinity IgE receptor (FceRI): from physiology to pathology. Annu Rev Immunol 1999; 17: 931-972. 
33 Kawakami T, Galli SJ. Regulation of mast-cell and basophil function and survival by IgE. Nat Rev Immunol 2002; 2: 773-786.

34 Grünig G, Warnock M, Wakil AE, et al. Requirement for IL13 independently of IL-4 in experimental asthma. Science 1998; 282: 2261-2263.

35 Wills-Karp M, Luyimbazi J, Xu X, et al. Interleukin-13: central mediator of allergic asthma. Science 1998; 282: 2258-2261.

36 Taube C, Duez C, Cui ZH, et al. The role of IL-13 in established allergic airway disease. J Immunol 2002; 169: 6482-6489.

37 Benyon RC, Bissonnette EY, Befus AD. Tumor necrosis factor- $\alpha$ dependent cytotoxicity of human skin mast cells is enhanced by anti-IgE antibodies. J Immunol 1991; 147: 2253-2258.

38 Walsh LJ, Trinchieri G, Waldorf HA, Whitaker D, Murphy GF. Human dermal mast cells contain and release tumor necrosis factor- $\alpha$, which induces endothelial leukocyte adhesion molecule 1. Proc Natl Acad Sci USA 1991; 88: 4220-4224.

39 Zhang Y, Ramos BF, Jakschik BA. Neutrophil recruitment by tumor necrosis factor from mast cells in immune complex peritonitis. Science 1992; 258: 1957-1959.

40 Echtenacher B, Männel DN, Hültner L. Critical protective role of mast cells in a model of acute septic peritonitis. Nature 1996; 381: 75-77.

41 von Stebut E, Metz M, Milon G, Knop J, Maurer M. Early macrophage influx to sites of cutaneous granuloma formation is dependent on MIP- $1 \alpha / \beta$ released from neutrophils recruited by mast cell-derived TNF $\alpha$. Blood 2003; 101: 210-215.

42 Rijnierse A, Koster AS, Nijkamp FP, Kraneveld AD. TNF- $\alpha$ is crucial for the development of mast cell-dependent colitis in mice. Am J Physiol Gastrointest Liver Physiol 2006; 291: G969-G976.

43 Biedermann $\mathrm{T}$, Kneilling M, Mailhammer R, et al. Mast cells control neutrophil recruitment during T cell-mediated delayed-type hypersensitivity reactions through tumor necrosis factor and macrophage inflammatory protein 2 . J Exp Med 2000; 192: 1441-1452.

44 van Houwelingen AH, Kool M, de Jager SC, et al. Mast cellderived TNF- $\alpha$ primes sensory nerve endings in a pulmonary hypersensitivity reaction. J Immunol 2002; 168: 5297-5302.

45 Casale TB, Costa JJ, Galli SJ. TNF- $\alpha$ is important in human lung allergic reactions. Am J Respir Cell Mol Biol 1996; 15: 35-44.

46 Busse PJ, Zhang TF, Srivastava K, et al. Chronic exposure to TNF- $\alpha$ increases airway mucus gene expression in vivo. J Allergy Clin Immunol 2005; 116: 1256-1263.

47 Choi IW, Sun K, Kim YS, et al. TNF- $\alpha$ induces the latephase airway hyperresponsiveness and airway inflammation through cytosolic phospholipase $\mathrm{A}(2)$ activation. J Allergy Clin Immunol 2005; 116: 537-543.

48 Nakae S, Lunderius C, Ho LH, Schäfer B, Tsai M, Galli SJ. TNF can contribute to multiple features of ovalbumininduced allergic inflammation of the airways in mice. J Allergy Clin Immunol 2007; 119: 680-686.

49 Kim YS, Ko HM, Kang NI, et al. Mast cells play a key role in the development of late airway hyperresponsiveness through TNF- $\alpha$ in a murine model of asthma. Eur $J$ Immunol 2007; 37: 1107-1115.

50 Nakae S, Ho LH, Yu M, et al. Mast cell-derived TNF contributes to airway hyperreactivity, inflammation, and $\mathrm{TH} 2$ cytokine production in an asthma model in mice. J Allergy Clin Immunol 2007; 120: 48-55.

51 Erin EM, Leaker BR, Nicholson GC, et al. The effects of a monoclonal antibody directed against tumor necrosis factor- $\alpha$ in asthma. Am J Respir Crit Care Med 2006; 174: 753-762.

52 Berry MA, Hargadon B, Shelley M, et al. Evidence of a role of tumor necrosis factor- $\alpha$ in refractory asthma. $N$ Engl J Med 2006; 354: 697-708.

53 Howarth PH, Babu KS, Arshad HS, et al. Tumour necrosis factor $(\mathrm{TNF}-\alpha)$ as a novel therapeutic target in symptomatic corticosteroid dependent asthma. Thorax 2005; 60: 1012-1018.

54 van Rijt LS, Jung S, Kleinjan A, et al. In vivo depletion of lung $\mathrm{CD} 11 \mathrm{c}+$ dendritic cells during allergen challenge abrogates the characteristic features of asthma. J Exp Med 2005; 201: 981-991.

55 Jawdat DM, Albert EJ, Rowden G, Haidl ID, Marshall JS. IgE-mediated mast cell activation induces Langerhans cell migration in vivo. J Immunol 2004; 173: 5275-5282. 